\title{
Tonggyu-tang, a traditional Korean medicine, suppresses pro-inflammatory cytokine production through inhibition of MAPK and NF-KB activation in human mast cells and keratinocytes
}

Hyo In Kim', Se Hyang Hong ${ }^{1}$, Jin Mo Ku', Sooyeon Kang ${ }^{1}$, Tai Young Kim², Yong Cheol Shin ${ }^{2}$ and Seong-Gyu $\mathrm{Ko}^{2,3^{*}}$ iD

\begin{abstract}
Background: Allergic diseases including allergic rhinitis, asthma, and atopic dermatitis are increasing worldwide. Common medications used to treat these inflammatory disorders are anti-histamines and corticosteroids, but they have their own limitations such as short duration and severe side effects. Thus, interest in complementary and alternative medicine is continually growing. Here, we investigate the anti-inflammatory mechanisms of Tonggyutang (TGT), a traditional Korean medicine that has been used to treat patients with allergic nasal disorders.

Methods: We measured mRNA expressions and production of pro-inflammatory cytokines such as interleukin (IL)-4, IL-6, IL-8 and tumor necrosis factor alpha (TNF-a) by RT-PCR and ELISA assays in HMC-1 (human mast cell line-1) and $\mathrm{HaCaT}$ cells, immortalized human keratinocytes. Moreover, we evaluated the effect of TGT on two major inflammation-related pathways, mitogen activated protein kinase (MAPK) and NF-KB signaling pathway in these two cells.

Results: Our results revealed that that TGT significantly reduced the expression and production of inflammatory cytokines such as IL-4, IL-6, IL-8, and TNF-a in the agonist-treated HMC-1 and HaCaT cells. We also found that TGT suppressed MAPK signaling pathway including extracellular signal-regulated kinase (ERK), p38 mitogen-activated protein kinase (p38), and c-Jun N-terminal kinase (JNK) as well as NF-kB pathway, which are known to regulate inflammatory cytokine expression.
\end{abstract}

Conclusion: Taken together, our results demonstrate that TGT inhibits expression of pro-inflammatory cytokines by suppressing MAPK and NF-kB pathway in both mast cells and keratinocytes, suggesting the potential use of TGT in treating allergic inflammatory diseases.

Keywords: Tonggyu-tang, Anti-inflammation, Hmc-1, HaCaT, Mapk, NF-kB

\footnotetext{
* Correspondence: epiko@khu.ac.kr

${ }^{2}$ Department of Preventive Medicine, College of Korean Medicine, Kyung

Hee University, Kyungheedae-ro 26, Dongdaemun-gu, Seoul 02447, Republic

of Korea

${ }^{3}$ Department of Science in Korean Medicine, College of Oriental Medicine,

Kyung Hee University, Seoul 130-701, Republic of Korea

Full list of author information is available at the end of the article
} 


\section{Background}

Allergic diseases are often caused by numerous inflammatory mediators such as histamine, chemokines, and cytokines from immune cells, which are affected by inflammatory cytokines from $\mathrm{T}$ cells and immunoglobulin E (IgE) from B cells [1, 2]. When the allergens enter the human body, phagocytes such as dendritic cells and macrophages process and present them to T cells, resulting in differentiation of naïve $\mathrm{T}$ cells into cytotoxic $\mathrm{T}$ (Tc) cells or helper $\mathrm{T}$ (Th) cells. While activated Tc cells kill infected cells, Th cells, especially Th2 cells, release interleukin (IL)-4, IL-6 and IL-10 to induce B cells to produce IgE, which in turn activates mast cells for histamine secretion $[3,4]$.

Current medications commonly used to relieve symptoms of allergic reactions are anti-histamines and corticosteroids, but they have their own limitations such as short duration and severe side effects $[5,6]$. Thus, the use of complementary and alternative medicine to treat allergic diseases is largely gaining an interest. In traditional Korean Medicine, several herbal medicines have been used for the treatment of allergic inflammation. Especially, Tonggyu-tang (TGT) composed of 12 herbs (Table 1), similarly Pyeongwee-San [7], Biyeom-Tang [8], Hyeonggaeyeongyo-Tang [9] and So-Cheon-Ryon-Tang [10] have shown anti-inflammatory effects on patients with allergic nasal disorder.

TGT was first seen in Dongeuibogam, seventeenthcentury textbook on Korean medicine, written by the

Table 1 Components of TGT

\begin{tabular}{|c|c|c|}
\hline Tonggyu-tang; TGT & $\begin{array}{l}\text { Component } \\
\text { ratio }(\%)\end{array}$ & References \\
\hline Ledebouriella divaricata Hiroe & 6.46 & \\
\hline Angelica koreanum Kitagawa & 6.46 & \\
\hline Angelica tenuissima Nakai & 6.46 & 22 \\
\hline Cimicifuga heracleifolia Kom. & 6.46 & \\
\hline Pueraria thunbergiana Benth. & 6.46 & 23 \\
\hline Ligusticum wallichii var. officinale Yook. & 4.82 & \\
\hline Atractylodes lancea DC. & 9.69 & \\
\hline Thuja orientalisl. & 12.92 & $24-26$ \\
\hline Ephedra sinica Stapf. & 3.23 & $27,28,37$ \\
\hline Zanthoxylum schinifolium S.Z. & 3.23 & 29 \\
\hline Asarum sieboldii var. seoulense Nakai & 2.58 & 30,38 \\
\hline Glycyrrhiza glabra & 6.46 & $31-34,35$ \\
\hline $\begin{array}{l}\text { Astragalus membranaceus var. } \\
\text { mongholicus Bung }\end{array}$ & 12.92 & $12,13,36,39$ \\
\hline Xanthium strumarium L. & 6.46 & 14,40 \\
\hline Magnolia denudate Desr. & 2.94 & 15,41 \\
\hline Mentha arvensis var. piperascens Makinv. & 2.47 & 16,42 \\
\hline Total & 100 & \\
\hline
\end{tabular}

famous royal physician, Heo Joon [11]. In this study, we modified ingredients of the original TGT by adding Astragalus membranaceus var. mongholicus Bung, Xanthium strumarium L., Magnolia denudate Desr. and Mentha arvensis var. piperascens Makinv, which are known to possess anti-inflammatory activities [12-16].

Although TGT has been commonly used for the treatment of allergic diseases, its underlying molecular mechanism of anti-inflammatory effect is unknown yet. Therefore, we hereby investigate the anti-inflammatory effect and the detailed molecular mechanism of TGT in HMC-1 (human mast cell line-1) and $\mathrm{HaCaT}$ cells which both participate in allergic disorders.

\section{Methods}

\section{Chemicals and reagents}

TGT was provided by Hanpoong pharmaceutical company (Jeonju, Korea) in a form of powder, which was dissolved in D.W. Phorbol 12-myristate 13-acetate (PMA), dimethyl sulfoxide (DMSO), ionomycin, lipopolysaccharide (LPS) and 3-[4,5-dimetylthiazol-2-yl]-2,5-diphenyltetrazoliumbromide (MTT) were purchased from Sigma-Aldrich Co. (St. Louis, MO, USA). Dulbecco's phosphate-buffered saline (DPBS), Iscove's Modified Dulbecco's Medium (IMDM), Dulbecco's Modified Eagle's medium (DMEM), penicillin and streptomycin were obtained from WELGNE (Gyeongsan, Korea). 3-(4,5-dimethylthiazol-2-yl)-5-(3-carboxymethoxyphenyl)-2-(4-sulfophenyl)-2H-tetrazolium (MTT) was from Promega (Maddison, WI, USA). Fetal bovine serum (FBS) was obtained from GR scientific (Bedford, UK) and EZ-cytox was purchased from DoGEN (Seoul, Korea). Human mRNA primers (IL-4, IL-6, IL-8, IL-13, tumor necrosis factor alpha (TNF- $\alpha$ ), glyceraldehyde 3-phosphate dehydrogenase (GAPDH) were purchased from Bioneer (Daejeon, Korea). Antibodies were obtained from Cell signaling Technology, Inc. (Danvers, MA, USA), and enzyme-linked immunosorbent assays (ELISA) antibodies were obtained from BD Biosciences (San Jose, CA, USA) and R\&D Systems (Minneapolis, MN, USA).

\section{Cell culture and treatment}

HMC-1 cells were grown in IMDM and $\mathrm{HaCaT}$ cells in DMEM, all supplied with $1 \%$ penicillin and streptomycin and $10 \% \mathrm{FBS}$, incubated at $37{ }^{\circ} \mathrm{C}, 5 \% \mathrm{CO}_{2}$ and $95 \%$ humidity. HMC-1 cells were stimulated with $5 \mathrm{ng} / \mathrm{ml}$ horbol 12-myristate 13-acetate (PMA) (Sigma-Aldrich, St. Louis, MO, USA) plus $500 \mathrm{ng} / \mathrm{ml}$ ionomycin and $\mathrm{HaCaT}$ cells were stimulated with $1 \mu \mathrm{g} / \mathrm{ml}$ LPS. After stimulating cells, TGT was treated at various concentrations for $24 \mathrm{~h}$. 
Cell viability measurement with MTS assay or MTT assay HMC-1 cells HaCaT cells were treated with various concentrations of TGT $(0,10,20,50,100,200,500$ and $1000 \mu \mathrm{g} / \mathrm{ml}$ ) with or without $5 \mathrm{ng} / \mathrm{ml}$ PMA plus $500 \mathrm{ng} / \mathrm{ml}$ ionomycin or LPS $1 \mu \mathrm{g} / \mathrm{ml}$ After $24 \mathrm{~h}$, cells were treated with MTS or MTT reagent solution for $1 \mathrm{~h}$, then absorbance was measured at $490 \mathrm{~nm}$ or $540 \mathrm{~nm}$ using a microplate.

\section{RNA extraction and RT-PCR}

Total RNA was extracted using an R\&A blue ${ }^{\mathrm{Tm}}$ Total RNA Extraction Kit (iNtRON Biotech, Korea). For measurement of RNA concentration, a Nanodrop 1000 (Thermo Fisher scientific, Waltham, MA, USA) was used. cDNA was prepared from $1 \mu \mathrm{g}$ of total RNA using a cDNA synthesis kit (Takara Bio Inc., Kusatsu, Japan). $1 \mu \mathrm{l}$ of cDNA were used for RT-PCR assays. The list of primers used in this study is shown in Table 2.

\section{Cytokine release measurement with ELISA}

Enzyme-linked immunosorbent assay (ELISA) was performed using kits from R\&D systems (Minneapolis, MN, USA) and BD Biosciences (San Jose, CA, USA). Briefly, samples and cytokine standards were added in 96-well plates coated with coating buffer at $4{ }^{\circ} \mathrm{C}$ for overnight and After washing with $0.05 \%$ Tween-20 phosphate-buffered saline (PBST) and blocked plates using Assay diluent with antibodies of IL-4, IL-6, IL8, TNF- $\alpha$ (BD Biosciences, San Jose, CA, USA) and IL-13 (R\&D systems, Minneapolis, MN, USA), and incubated at $37{ }^{\circ} \mathrm{C}$ for $1 \mathrm{~h}$. After the plates were washed, biotinylated antibodies were added and the plates were left in RT for additional $2 \mathrm{~h}$. The plates were then washed, incubated with AP for $30 \mathrm{~min}$ at $37{ }^{\circ} \mathrm{C}$. Then TBS substrate solution was added and absorbance was measured at $450 \mathrm{~nm}$ by a microplate reader.

Table 2 Reverse-Transcriptase PCR primer sequences of oligonucleotide

\begin{tabular}{lll}
\hline Oligonucleotide & & \\
\hline GAPDH & F & GCT CTT CAC CAC CAT GGA GA \\
& R & CGC CCA TCA CGC CAC AGT TT \\
IL-4 & F & TGC CTC CAA GAA CAC AAC TG \\
& R & CTC TGG TTG GCT TCC TTC AC \\
IL-6 & F & AAC CTT CCA AAG ATG GCT GAA \\
& R & CAG GAA CTG GAT CAG GAC TT \\
IL-8 & F & TCA GTG CAT AAA GAC ATA CTCC \\
& R & TGG CAT CT CAC TGA TTC TTG \\
TNF-a & F & TGA GCA CTG AAA GCA TGA TCC \\
& R & ATC ACT CCA AAG TGC AGC AG \\
\hline
\end{tabular}

\section{Western blot assay}

Cells were harvested, washed with $1 \mathrm{ml}$ DPBS and lysed with RIPA buffer (150 mM NaCl, 1\% NP-40, 0.5\% DOC, 0.1\% SDS, $50 \mathrm{mM}$ Tris (pH 8.0), $1 \mathrm{mM}$ EDTA, $1 \mathrm{mM}$ PMSF, $1 \mathrm{mM} \mathrm{NaF}, 1 \mathrm{mM} \mathrm{Na} \mathrm{PO}_{4}$, $1 \mu \mathrm{g} / \mathrm{ml}$ aprotinin, leupeptin, pepstatin) and incubated in ice for $20 \mathrm{~min}$. Total cell lysates were then centrifuged at $13,000 \times g$ for $20 \mathrm{~min}$ at $4{ }^{\circ} \mathrm{C}$ to remove the insoluble materials. Next, the total concentration of extracted proteins was determined at $15 \mu \mathrm{g}$, and then separated by $10 \%$ sodium dodecyl sulfatepolyacrylamide gel electrophoresis (SDS-PAGE) and transferred onto nitrocellulose membranes. The membranes were blocked with $0.1 \%$ PBST supplied with $2 \%$ skimmed milk and $2 \%$ bovine serum albumin (BSA) (Sigma-Aldrich, St. Loius, MA, USA) for $1 \mathrm{~h}$ at RT. After 4 times of 15 min washing with PBST, the membranes were incubated with primary antibodies diluted at $1: 1000$ at $4{ }^{\circ} \mathrm{C}$ overnight. After incubation, the membranes were washed with PBS for $15 \mathrm{~min}, 4$ times, and then incubated with secondary antibodies diluted at 1:4000 for $1 \mathrm{~h}$ at RT. The protein signals were developed by the ECL detection kit (DoGEN, Seoul, Korea).

\section{Statistical analysis}

Results are expressed as the mean \pm standard error (S.E.) of independent experiments, and statistical analyses were performed using ONEWAY ANOVA to determine differences between groups. All statistical analyses were performed using GraphPad Prism 5 (GraphPad Software, Inc., La Jolla, CA, USA). Values with $p<0.05$ and ${ }^{\#} p<0.05$ are considered to indicate statistical significance.

\section{Results \\ Effect of TGT on expression and production of inflammatory cytokines in HMC-1 cells}

In order to examine the anti-inflammatory effects of TGT, we used the human mast cell line-1, HMC-1 cells, one of the most representative cells for studying inflammatory response. First, to evaluate the effect of TGT on HMC-1 cell viability, an MTS assay was performed. As a result, TGT did not affect HMC-1 viability up to concentration of $1000 \mu \mathrm{g} / \mathrm{ml}$ (Additional file 1: Fig. S1a). Next, to evaluate the anti-inflammatory effect of TGT, HMC-1 cells were stimulated with both PMA and ionomycin (PI), followed by treatment with various concentrations of TGT (100, 200, 500, $1000 \mu \mathrm{g} / \mathrm{ml})$. As in Fig. 1a and b, PI treatment of HMC-1 cells increased mRNA levels of IL-4, IL- 6 and TNF- $\alpha$. Adding of TGT significantly reduced the mRNA expression of these cytokines. Note that in the 

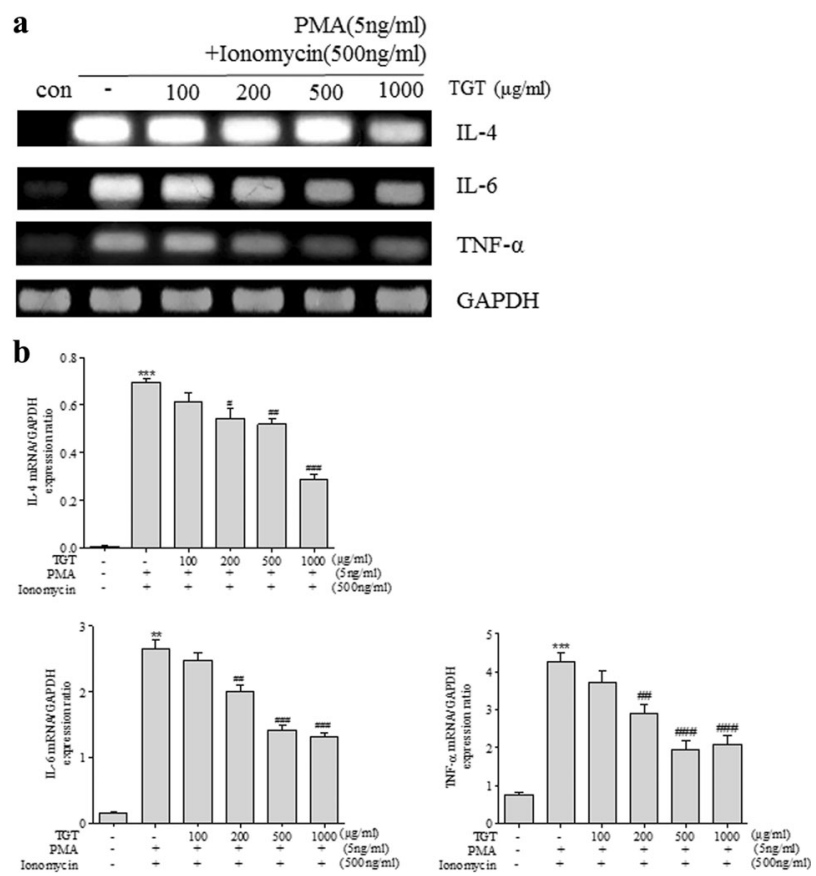

Fig. 1 Effect of TGT on expression of pro-inflammatory cytokines in PI stimulated HMC-1 cells. a PI-stimulated HMC-1 cells were treated with or without different doses of TGT for $24 \mathrm{~h}$. Cytokine mRNA levels were measured by RT-PCR. $\mathbf{b}$ The density of each band was calculated with image processing program, Image J, and represented as bar graphs. *; compared to control. \#; compared to stimulated cells. Control; HMC-1 with PI (-), Stimulation; HMC-1 with PI (+)

PI-treated HMC-1 cells, TGT did not cause significant cell cytotoxicity up to $1000 \mu \mathrm{g} / \mathrm{ml}$ as well (Additional file 1: Fig. S1b). Furthermore, we assessed the effect of TGT on cytokine production by ELISA. As shown in Fig. 2, TGT treatment significantly reduced production of IL-4, IL- 6 and TNF- $\alpha$ in the PI-treated HMC-1 cells.

\section{Effect of TGT on MAPK signaling pathway in HMC-1 cells} To understand the molecular mechanism underlying the inhibitory effects of TGT on cytokine expression, we examined the mitogen activated protein kinase (MAPK) signaling pathway that is known to be closely related to allergy diseases by regulating the expressions of inflammatory cytokines such as TNF- $\alpha$ and IL-6 [17, 18]. We observed that TGT treatment of HMC-1 cells suppressed the PI-induced activation of extracellular signal-regulated kinase (ERK), p38 mitogen-activated protein kinase (p38), and c-Jun $\mathrm{N}$ terminal kinase (JNK) in a dose-dependent manner (Fig. 3a).

\section{Effect of TGT on NF-kB signaling pathway in HMC-1 cells} NF- $\mathrm{kB}$ also plays a pivotal role in immune responses by regulating the expressions of various inflammatory cytokines. Under phosphorylated and degraded situations of
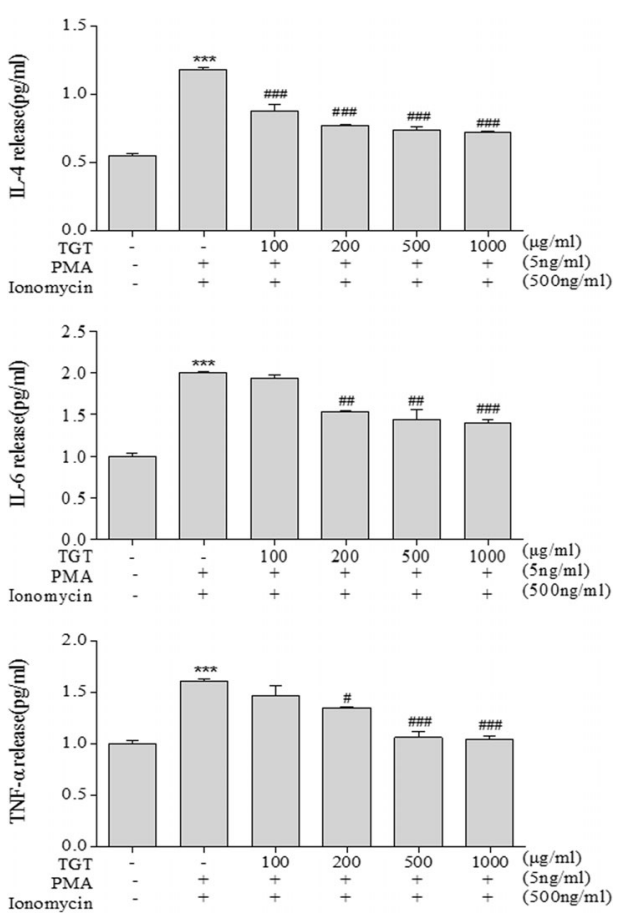

Fig. 2 Effect of TGT on the release of pro-inflammatory cytokines in HMC-1 cells. PI-stimulated HMC-1 cells were treated with or without different doses of TGT for $24 \mathrm{~h}$. The levels of secreted pro-inflammatory cytokines in the cell culture supernatant were measured by ELISA. *; compared to control. \#; compared to stimulated cells. Control; HMC-1 with PI (-), Stimulation; HMC-1 with PI (+) 


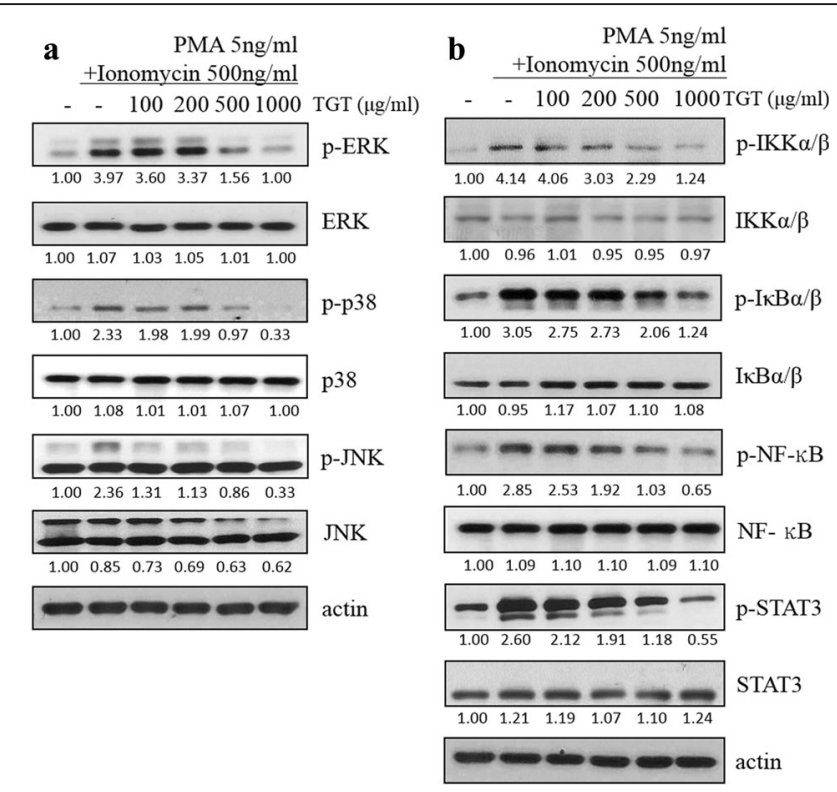

Fig. 3 Effect of TGT on the protein expressions of MAPK and NF-KB signaling pathways in HMC-1 cells. PI-stimulated HMC-1 cells were treated with or without different doses of TGT for $24 \mathrm{~h}$. The levels of protein expressions of (a) MAPK signaling pathway and (b) NF-KB signaling pathway in the whole cell lysates of HMC-1 cells were measured by western blot assays

I $\mathrm{kB}, \mathrm{NF}-\mathrm{kB}$ are translocated into the nucleus, then initiate inflammatory-related gene transcription $[19,20]$. We found that increased phosphorylation levels of $I K K \alpha / \beta$, $\mathrm{I} \kappa \mathrm{B} \alpha / \beta$, as well as STAT3 by PI treatment were inhibited by TGT co-treatment in a dose-dependent manner in HMC-1 cells (Fig. 3b).

\section{Effect of TGT on inflammatory cytokines in HaCaT cells}

Given that TGT suppresses the cytokine expression in HMC-1 cells, we next investigated the inhibitory effect of TGT on cytokine expression in $\mathrm{HaCaT}$ cells, an immortalized human keratinocytes. Of note, TGT did not show significant cytotoxicity in mock or LPS-treated $\mathrm{HaCaT}$ cells (Additional file 2: Fig. S2). Similar to HMC1 cells, treatment of $\mathrm{HaCaT}$ cells with TGT markedly reduced the LPS-induced expression and production of inflammatory cytokines including IL-4, IL-6, IL-8 and TNF- $\alpha$, as measured by RT-PCR and ELISA, respectively (Figs. 4 and 5).

\section{Discussion}

Allergic diseases such as allergic rhinitis, atopic dermatitis and asthma share a number of pathogenic and epidemiological features. Although detailed mechanisms of these diseases at the cellular level are still unclear, recent studies have focused on the roles of immune cells, especially Th2 cells in the pathogenesis of these allergic disorders [21].

TGT is an herbal medicine composed of 12 different herbs that are frequently used for treatment of patients with nasal disorder [11]. In this study, we added 4 additional anti-inflammatory herbs including Astragalus membranaceus, Xanthium strumarium, Magnolia denudate, and Mentha arvensis, to the original constituents to increase TGT's anti-allergic effects. Among these 16 herbs in the formulation of TGT, a number of studies

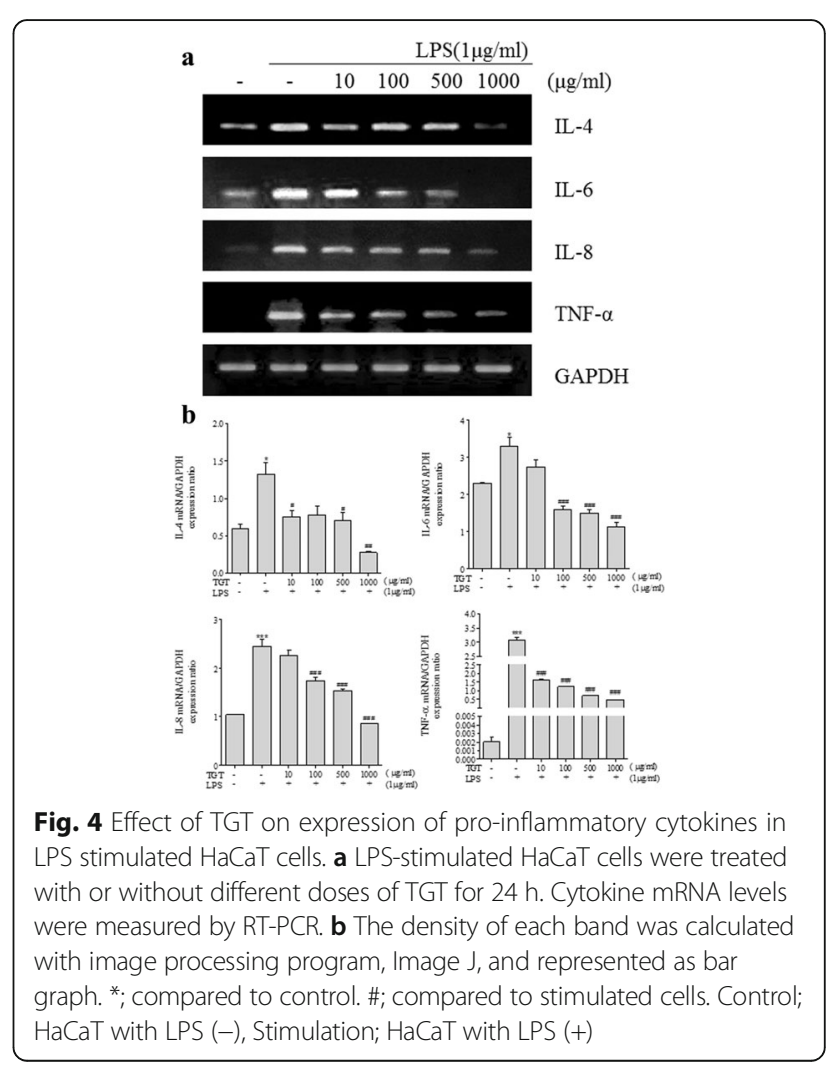



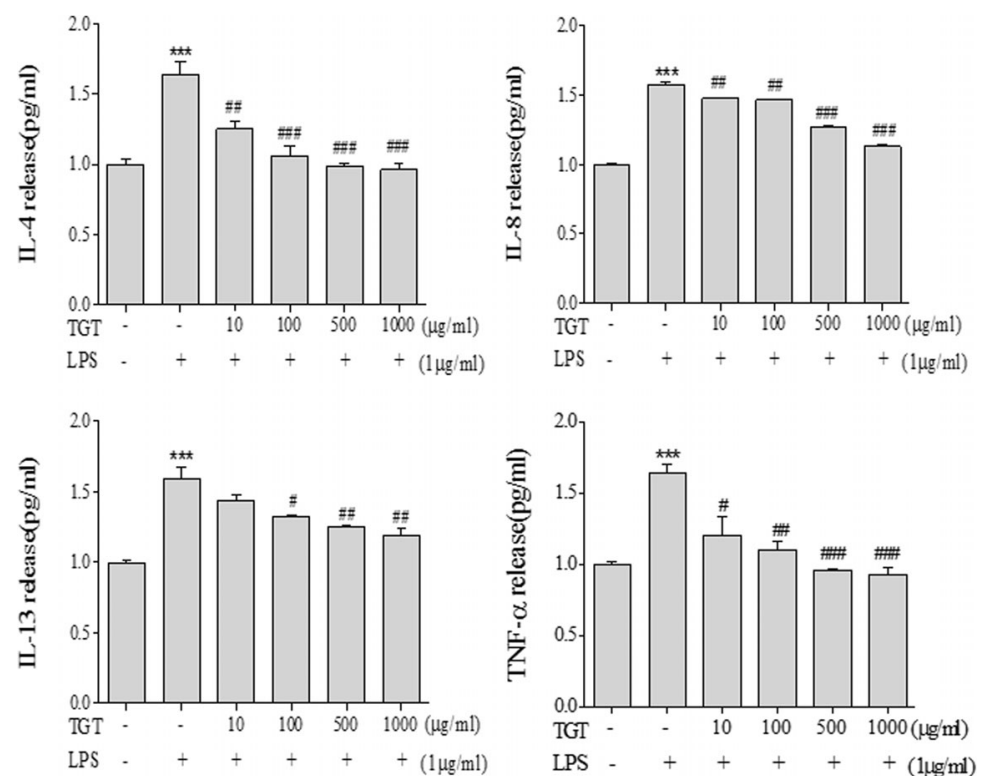

Fig. 5 Effect of TGT on the release of pro-inflammatory cytokines in HaCaT cells. LPS-stimulated HaCaT cells were treated with or without different doses of TGT for $24 \mathrm{~h}$. The levels of secreted pro-inflammatory cytokines in the cell culture supernatant were measured by ELISA. *; compared to control. \#; compared to stimulated cells. Control; HaCaT with LPS (-), Stimulation; HaCaT with LPS (+)

have showed that extracts or an active compound from individual herbs have anti-inflammatory activities (Table 1) [12-16, 22-36]. Especially, six herbs including Ephedra sinica and Asarum sieboldii have been reported to have anti-histamine actions like inhibition of histamine release from mast cells or several histamine-mediated biological processes [37-42].

Since no studies have been performed to examine cellular and molecular actions of TGT, we sought to investigate the effects of TGT on human mast cells and keratinocytes. Mast cells play a key role in the development of allergic responses by releasing inflammatory mediators such as TNF- $\alpha$, IL-6, IL-8, IL-13, and histamine $[43,44]$. IL-6 stimulates the growths of neutrophils and B cells, and IL-13 influence the apoptosis and survival of eosinophils, respectively [45-47].

In this study, we showed that TGT significantly reduced the expression and production of inflammatorycytokines in both HMC-1 and $\mathrm{HaCaT}$ cells. MAPK such as ERK, p38, and JNK are closely involved in the synthesis of inflammation mediators. Therefore, inhibitors targeting MAPKs are developed to reduce inflammation [48]. Our findings showed that TGT inhibits agonistinduced MAPK activation in a dose-dependent manner. Furthermore, we found that TGT treatment suppressed the agonist-induced activation of NF- $\mathrm{kB}$ pathway which is another important cellular signaling pathway for production of inflammatory cytokines. Overall, our results suggest that TGT can be effective treatment option for patients with inflammatory disorders including allergic rhinitis, atopic dermatitis through suppressing MAPK and NF- $\mathrm{KB}$ mediated production of inflammatory cytokines.

\section{Conclusions}

Our results clearly indicate that TGT has suppressing activity on expression and production of pro-inflammatory cytokines through inhibition of MAPK and NF-kB signaling pathways in mast cells and keratinocytes. Therefore, TGT can be used to reduce inflammatory symptoms in allergic disorders including not only allergic rhinitis but also atopic dermatitis and asthma.

\section{Additional files}

Additional file 1: Figure S1. Effect of TGT on the viability of PMA and Ionomycin (PI)-stimulated HMC-1 cells. Various concentration of TGT was added to PI treated HMC-1 cells. Cell viability was measured by MTS assay. *; compared to control. \#; compared to stimulated cells. Control; HMC-1 with PI (-), Stimulation; HMC-1 with PI (+). (TIFF $82 \mathrm{~kb}$ )

Additional file 2: Figure S2. Effect of TGT on the viability of LPSstimulated $\mathrm{HaCaT}$ cells. Various concentration of TGT was added to LPS treated $\mathrm{HaCaT}$ cells. Cell viability was measured by MTT assay. *; compared to control. \#; compared to stimulated cells. Control; HaCaT with LPS (-), Stimulation; HaCaT with LPS (+). (TIFF $91 \mathrm{~kb}$ )

\section{Abbreviations}

ANOVA: One-way analysis of variance; DMEM: Dulbecco's Modified Eagle's medium; DMSO: dimethyl sulfoxide; DPBS: Dulbecco's phosphate-buffered saline; ELISA: enzyme-linked immunosorbent assays; ERK: extracellular signalregulated kinase; ;BS: fetal bovine serum; GAPDH: glyceraldehyde 3phosphate dehydrogenase; HMC-1: human mast cell line-1; 
IgE: immunoglobulin E; IL: Interleukin; IMDM: Iscove's Modified Dulbecco's Medium; JNK: c-Jun N-terminal kinase; LPS: Lipopolysaccharide; MAPK: Mitogen activated protein kinase; MTS: 3-(4,5-dimethylthiazol-2-yl)-5(3-carboxymethoxyphenyl)-2-(4-sulfophenyl)-2H-tetrazolium; MTT: 3-[4,5dimetylthiazol-2-yl]-2,5-diphenyltetrazoliumbromide; p38: p38 mitogenactivated protein kinase; PBST: Tween-20 phosphate-buffered saline; PI: PMA and ionomycin; PMA: Phorbol 12-myristate 13-acetate; SDS-PAGE: sodium dodecyl sulfate-polyacrylamide gel electrophoresis (SDS-PAGE); Tc: Cytotoxic T; TGT: Tonggyu-tang; Th: Helper T; TNF-a: Tumor necrosis factor alpha

\section{Acknowledgements}

Not applicable.

\section{Funding}

This research was supported by a grant from Korean Medicine R\&D Project of the Ministry of Health and Welfare (H12C1889).

\section{Availability of data and materials}

Materials and data of this study are available to other researchers upon request.

\section{Authors' contributions}

Conceived and designed the experiments: HIK and S-GK; Performed the experiments: HIK, SHH, JMK and S-YK; Analyzed the data: HIK and TYK; Contributed reagents/materials/analysis tools: TYK, YCS and S-GK; Wrote the paper: HIK. All authors read and approved the final manuscript.

\section{Competing interest}

The authors declare that they have no competing interests.

\section{Consent for publication}

Not applicable.

\section{Ethics approval and consent to participate}

Not applicable.

\section{Author details}

${ }^{1}$ Department of Science in Korean Medicine, Graduate School, Kyung Hee University, Kyungheedae-ro 26, Dongdaemun-gu, Seoul 02447, Republic of Korea. ${ }^{2}$ Department of Preventive Medicine, College of Korean Medicine, Kyung Hee University, Kyungheedae-ro 26, Dongdaemun-gu, Seoul 02447, Republic of Korea. ${ }^{3}$ Department of Science in Korean Medicine, College of Oriental Medicine, Kyung Hee University, Seoul 130-701, Republic of Korea.

Received: 3 December 2016 Accepted: 23 March 2017 Published online: 31 March 2017

\section{References}

1. Bradding P, Feather $\mathrm{IH}$, Wilson $\mathrm{S}$, Bardin PG, Heusser $\mathrm{CH}$, Holgate $\mathrm{ST}$, et al. Immunolocalization of cytokines in the nasal mucosa of normal and perennial rhinitic subjects. The mast cell as a source of IL-4, IL-5, and IL-6 in human allergic mucosal inflammation. J Immunol. 1993;151(7):3853-65.

2. Minty A, Chalon P, Derocq JM, Dumont X, Guillemot JC, Kaghad M, et al. Interleukin-13 is a new human lymphokine regulating inflammatory and immune responses. Nature. 1993;362(6417):248-50.

3. Hammad H, Lambrecht BN. Dendritic cells and epithelial cells: linking innate and adaptive immunity in asthma. Nat Rev Immunol. 2008;8(3):193-204.

4. Holgate ST, Polosa R. Treatment strategies for allergy and asthma. Nat Rev Immunol. 2008;8(3):218-30.

5. Hoyte FC, Katial RK. Antihistamine therapy in allergic rhinitis. Immunol Allergy Clin N Am. 2011;31(3):509-43.

6. Hajar T, Leshem YA, Hanifin JM, Nedorost ST, Lio PA, Paller AS, et al. A systematic review of topical corticosteroid withdrawal ("steroid addiction") in patients with atopic dermatitis and other dermatoses. J Am Acad Dermatol. 2015;72(3):541-9. e2

7. Oh HA, Kim HM, Jeong HJ. Alleviation of allergic rhinitis symptoms with Pyeongwee-san extract (KMP6). Immunopharmacol Immunotoxicol. 2012;34(1):135-42.

8. Jeong KT, Kim SG, Lee J, Park YN, Park HH, Park NY, et al. Anti-allergic effect of a Korean traditional medicine, Biyeom-tang on mast cells and allergic rhinitis. BMC Complement Altern Med. 2014;14:54.
9. Hong SH, Kim SR, Choi HS, Ku JM, Seo HS, Shin YC, et al. Effects of Hyeonggaeyeongyo-tang in ovalbumin-induced allergic rhinitis model. Mediat Inflamm. 2014;2014:418705.

10. Ku JM, Hong SH, Kim SR, Choi HS, Seo HS, Jang BH, et al. Anti-allergic effects of so-Cheong-Ryong-tang in ovalbumin-induced allergic rhinitis model. Eur Arch Otorhinolaryngol. 2016;273(1):123-31.

11. Lee K-J, Nam H-J, Kim Y-B. Effect of Tongqiao-tang on OVA induced allergic rhinitis mouse model. The Journal of Korean Oriental Medicine. 2008;29(5):96-103.

12. Ryu M, Kim EH, Chun M, Kang S, Shim B, Yu YB, et al. Astragali radix elicits anti-inflammation via activation of MKP-1, concomitant with attenuation of p38 and Erk. J Ethnopharmacol. 2008;115(2):184-93.

13. Qin Q, Niu J, Wang Z, Xu W, Qiao Z, Gu Y. Astragalus Membranaceus inhibits inflammation via phospho-P38 mitogen-activated protein kinase (MAPK) and nuclear factor (NF)-kappaB pathways in advanced glycation end product-stimulated macrophages. Int J Mol Sci. 2012;13(7):8379-87.

14. Yeom M, Kim JH, Min JH, Hwang MK, Jung HS, Sohn Y. Xanthii fructus inhibits inflammatory responses in LPS-stimulated RAW 264.7 macrophages through suppressing NF-kappaB and JNK/p38 MAPK. J Ethnopharmacol. 2015:176:394-401.

15. Kim D-Y, Jeong W-S, Moon H-C, Park S-J. Water extract of flowers of Magnolia denudata inhibits LPS-induced nitric oxide and pro-inflammatory cytokines production in Murine peritoneal macrophage by inhibiting NF-\{kkappa\}B activation. Korean Journal of Oriental Physiology and Pathology. 2007;21(4):916-20.

16. Verma SM, Arora H, Dubey R. Anti - inflammatory and sedative - hypnotic activity of the methanolic extract of the leaves of Mentha arvensis. Anc Sci Life. 2003;23(2):95-9.

17. Kyriakis JM, Avruch J. Mammalian MAPK signal transduction pathways activated by stress and inflammation: a 10-year update. Physiol Rev. 2012;92(2):689-737.

18. Pearson G, Robinson F, Beers Gibson T, Xu BE, Karandikar M, Berman K, et al. Mitogen-activated protein (MAP) kinase pathways: regulation and physiological functions. Endocr Rev. 2001;22(2):153-83.

19. Finco TS, Baldwin AS. Mechanistic aspects of NF-kappa B regulation: the emerging role of phosphorylation and proteolysis. Immunity. 1995;3(3):263-72.

20. Barnes PJ, Karin M. Nuclear factor-kappaB: a pivotal transcription factor in chronic inflammatory diseases. N Engl J Med. 1997;336(15):1066-71.

21. Zheng T, Yu J, Oh MH, Zhu Z. The atopic march: progression from atopic dermatitis to allergic rhinitis and asthma. Allergy Asthma Immunol Res. 2011;3(2):67-73.

22. Kim H, Bae S, Kwon KY, Hwang Yl, Kang JS, Lee WJ. A combinational effect of acetaminophen and oriental herbs on the regulation of inflammatory mediators in microglia cell line, BV2. Anat Cell Biol. 2015;48(4):244-50.

23. Min SW, Park YJ, Kim DH. Kakkalide and its metabolite irisolidone ameliorate carrageenan-induced inflammation in mice by inhibiting NF-kappaB pathway. Inflammation. 2011;34(5):344-51.

24. Lee YJ, Hwang SM, Yoon JJ, Lee SM, Kyung EH, Kim JS, et al. Inhibitory effect of Thuja orientalis on TNF-alpha-induced vascular inflammation. Phytother Res. 2010;24(10):1489-95.

25. Jung HW, Kang SY, Park KH, Oh TW, Jung JK, Kim SH, et al. Effect of the semen extract of Thuja orientalis on inflammatory responses in transient focal cerebral ischemia rat model and LPS-stimulated BV-2 microglia. Am J Chin Med. 2013;41(1):99-117.

26. Shin IS, Shin NR, Jeon CM, Kwon OK, Hong JM, Kim HS, et al. Thuja orientalis Reduces airway inflammation in ovalbumin-induced allergic asthma. Mol Med Rep. 2015;12(3):4640-6.

27. Yeom GG, Min S, Kim SY. 2,3,5,6-Tetramethylpyrazine of Ephedra sinica regulates melanogenesis and inflammation in a UVA-induced melanoma/ keratinocytes co-culture system. Int Immunopharmacol. 2014;18(2):262-9.

28. Wang $Q$, Shu Z, Xing N, Xu B, Wang C, Sun G, et al. A pure polysaccharide from Ephedra sinica treating on arthritis and inhibiting cytokines expression. Int J Biol Macromol. 2016;86:177-88.

29. Cao LH, Lee YJ, Kang DG, Kim JS, Lee HS. Effect of Zanthoxylum schinifolium on TNF-alpha-induced vascular inflammation in human umbilical vein endothelial cells. Vasc Pharmacol. 2009;50(5-6):200-7.

30. Quang TH, Ngan NT, Minh CV, Kiem PV, Tai BH, Thao NP, et al. Anti-inflammatory and PPAR transactivational effects of secondary metabolites from the roots of Asarum Sieboldii. Bioorg Med Chem Lett. 2012;22(7):2527-33. 
31. Ram A, Mabalirajan U, Das M, Bhattacharya I, Dinda AK, Gangal SV, et al. Glycyrrhizin alleviates experimental allergic asthma in mice. Int Immunopharmacol. 2006;6(9):1468-77.

32. Genovese T, Menegazzi M, Mazzon E, Crisafulli C, Di Paola R, Dal Bosco M, et al. Glycyrrhizin reduces secondary inflammatory process after spinal cord compression injury in mice. Shock. 2009;31 (4):367-75.

33. Chu X, Ci X, Wei M, Yang X, Cao Q, Guan M, et al. Licochalcone a inhibits lipopolysaccharide-induced inflammatory response in vitro and in vivo. J Agric Food Chem. 2012;60(15):3947-54.

34. Li C, Eom T, Jeong Y. Glycyrrhiza glabra L. Extract inhibits LPS-induced inflammation in RAW macrophages. J Nutr Sci Vitaminol (Tokyo) 2015, 61(5):375-381.

35. Gonzalez-Reyes S, Santillan-Cigales JJ, Jimenez-Osorio AS, Pedraza-Chaverri J, Guevara-Guzman R. Glycyrrhizin ameliorates oxidative stress and inflammation in hippocampus and olfactory bulb in lithium/pilocarpineinduced status epilepticus in rats. Epilepsy Res. 2016;126:126-33.

36. Zhang WJ, Hufnagl P, Binder BR, Wojta J. Antiinflammatory activity of astragaloside IV is mediated by inhibition of NF-kappaB activation and adhesion molecule expression. Thromb Haemost. 2003;90(5):904-14.

37. Chu XP, Xu ZH, Zhan GX, Wu DZ, Qiu MF, Jia W. Study on the proportion \& mechanism of reliving asthma of drug partnership comprising herbal Ephedrae sinica \& Pheretima aspergilum. Zhongguo Zhong Yao Za Zhi. 2006;31(3):236-9.

38. Kim SJ, Gao Zhang C, Taek LJ. Mechanism of anti-nociceptive effects of Asarum Sieboldii Miq. Radix: potential role of bradykinin, histamine and opioid receptor-mediated pathways. J Ethnopharmacol. 2003:88(1):5-9.

39. Luo GJ, Gan XL, Hei ZQ, Chen LX, Li SR. Effect of Astragalus membranacaus injection on activity of intestinal mucosal mast cells and inflammatory response after hemorrahagic shock-reperfusion in rats. Zhongguo Zhong Yao Za Zhi. 2007;32(14):1436-40.

40. Hong SH, Oh MJ, Lee EJ, Park JH, Kim NH, Rhee HK, et al. Processed Xanthii fructus increases cell viability of mast cell line, RBL-2H3. Orient Pharm Exp Med. 2004:4(1):60-4.

41. Shen Y, Pang EC, Xue CC, Zhao ZZ, Lin JG, Li CG. Inhibitions of mast cellderived histamine release by different Flos Magnoliae species in rat peritoneal mast cells. Phytomedicine. 2008;15(10):808-14.

42. Shin TY. Inhibition of immunologic and nonimmunologic stimulationmediated anaphylactic reactions by the aqueous extract of Mentha arvensis. Immunopharmacol Immunotoxicol. 2003;25(2):273-83.

43. Stassen M, Muller C, Arnold M, Hultner L, Klein-Hessling S, Neudorfl C, et al. IL-9 and IL-13 production by activated mast cells is strongly enhanced in the presence of lipopolysaccharide: NF-kappa B is decisively involved in the expression of IL-9. J Immunol. 2001;166(7):4391-8.

44. Barnes PJ, Adcock I. Anti-inflammatory actions of steroids: molecular mechanisms. Trends Pharmacol Sci. 1993;14(12):436-41.

45. Ershler WB, Keller ET. Age-associated increased interleukin-6 gene expression, late-life diseases, and frailty. Annu Rev Med. 2000;51:245-70.

46. Wedi B, Raap U, Lewrick H, Kapp A. IL-4-induced apoptosis in peripheral blood eosinophils. J Allergy Clin Immunol. 1998;102(6 Pt 1):1013-20.

47. Levi-Schaffer F, Temkin V, Malamud V, Feld S, Zilberman Y. Mast cells enhance eosinophil survival in vitro: role of TNF-alpha and granulocytemacrophage colony-stimulating factor. J Immunol. 1998;160(11):5554-62

48. Zheng T, Oh MH, Oh SY, Schroeder JT, Glick AB, Zhu Z. Transgenic expression of interleukin-13 in the skin induces a pruritic dermatitis and skin remodeling. J Invest Dermatol. 2009;129(3):742-51.

\section{Submit your next manuscript to BioMed Central and we will help you at every step:}

- We accept pre-submission inquiries

- Our selector tool helps you to find the most relevant journal

- We provide round the clock customer support

- Convenient online submission

- Thorough peer review

- Inclusion in PubMed and all major indexing services

- Maximum visibility for your research

Submit your manuscript at www.biomedcentral.com/submit
Biomed Central 